[Agr. Biol. Chem., Vol. 36, No. 1, p. 146 153, 1972]

\title{
Purification and Properties of Pectin trans-Eliminase from Aspergillus sojae
}

\author{
By Shigetaka IsHII and Tamotsu YokotsukA \\ Central Research Laboratories of Kikkoman Shoyu Co. Lid., \\ 399 Noda, Noda-shi, Chiba-ken, Japan \\ Received August 10, 1971
}

\begin{abstract}
Pectin transeliminase from the culture medium of Aspergillus sojae was purified 940-fold by ammonium sulfate fractionation, column chromatography on CM-Cellulose, DEAESephadex and SE-Sephadex and gel filtration. The purified enzyme was free from polygalacturonase, hemicellulase, cellulase and protease, and was almost homogeneous on disc electrophoresis. Using gel filtration a molecular weight of about 32,000 was estimated for the enzyme. The pH optimum of the enzyme for pectin $(68 \%$ esterified) was 5.5 , but was 7.0 for polymethyl polygalacturonate methyl glycoside (98\% esterified). The addition of divalent cation to pectin stimulated the activity and shifted the $\mathrm{pH}$ optimum to neutral side. This tendency by divalent cation, however, was not observed when polymethyl polygalacturonate methyl glycoside was used as substrate. The enzyme is stable between $\mathrm{pH} 4$ to 7 . Heating the enzyme solution at $70^{\circ} \mathrm{C}$ for $10 \mathrm{~min}$ caused complete loss of activity. A marked inhibition of activity was produced by oxidizing reagents such as iodine and N-bromosuccinimide. In contrast, no effect emerged from the action of chelating agents, reducing reagents and those reagents which convert $\mathrm{SH}$-groups in protein into mercaptides. The limits of degradation of pectin and polymethyl polygalacturonate methyl glycoside by the enzyme were 26.3 and $39.8 \%$, respectively.
\end{abstract}

In 1960 Albersheim et al. ${ }^{1 !}$ reported an enzyme which degraded $\alpha-1,4$ galacturonide linkages in pectin by a trans-elimination mechanism. The enzyme, namely, pectin transeliminase (PTE) (E.C. 4.2.99) is specific for methyl-esterified galacturonide linkage.

Similar enzymes (pectic acid transeliminase), which are specific for non-esterified galacturonide linkage, have been reported to be found in bacteria. ${ }^{2 \sim 5}$ However, the properties of PTE have not been known in detail, because only a few reports have been published so far. ${ }^{6-81}$

In the course of an investigation of the enzymatic degradation of plant cell walls by Aspergillus sojae, we found that the fungus produced PTE extracellularly in significant amounts, ${ }^{9 \prime}$ and the enzyme was able to macerate various kinds of plant tissue by itself. ${ }^{101}$
PTE of this fungus was also found to be able to clarify the cloudy fruit juice such as those of apple and grape. ${ }^{111}$

The present paper describes the purification and properties of PTE from Asp. sojae.

\section{MATERIALS AND METHODS}

Pectic substances. Pectin was obtained from Sunkist Growers, Inc. It was washed three times with $700^{\circ}$ $(\mathrm{v} / \mathrm{v})$ ethanol to remove soluble sugars. Polymethyl polygalacturonate methyl glycoside (Link pectin) was prepared by the methed of Morell et al.12) The degrees of esterification of pectin and Link pectin were 68 and $98 \%$, respectively.

Cultivation of Aspergillus sojae. Asp. sojae No. 48 was grown on $400 \mathrm{~g}$ of wheat bran moistened with $320 \mathrm{ml}$ of water in wooden boxes $(60 \times 30 \times 5 \mathrm{~cm})$ at $30^{\circ} \mathrm{C}$ for 3 days. 
Assay of PTE activity. PTE was determined by spectrophotometry. Reaction mixtures containing 0.5 $\mathrm{ml}$ of enzyme solution, $1.0 \mathrm{ml}$ of $1 \%$ pectin and 1.0 $\mathrm{ml}$ of Mcllvaine buffer, $\mathrm{pH} 5.5$, were incubated at $40^{\circ} \mathrm{C}$ for a definite period. Increase in an absorbance at $235 \mathrm{~m} \ell$ was measured using a Hitachi Model 101 spectrophotometer. One unit of PTE was defined as the increase of absorbance at $235 \mathrm{~m} \mu$ by 1.0 in the reaction mixture per min.

Protein concentration. Protein concentrations were determined by the method of Lowry et al, ${ }^{131}$ by using bovine serum albumin as a standard.

\section{RESULTS}

\section{Purification of enzyme}

All procedures were carried out at $0 \sim 4^{\circ} \mathrm{C}$ except otherwise stated.

Step 1. Extraction. To $8 \mathrm{~kg}$ of bran culture of Asp. sojae No. 48 were added 40 liters of water. The suspension was stirred at room temperature for $2 \mathrm{hr}$, and filtered with cotton cloth. Clear extract (34 liters) was obtained by further filtration with celite.

Step 2. Ammonium sulfate fractionation. Solid ammonium sulfate $(10.2 \mathrm{~kg})$ was added to clear extract with continuous stirring. After standing for $4 \mathrm{hr}$, the precipitates formed were removed by centrifugation at $8000 \times g$ for $10 \mathrm{~min}$. To the supernatant ammonium sulfate $(9.2 \mathrm{~kg})$ was added with stirring. After standing overnight, the precipitates formed were collected by centrifugation at $8000 \times g$ for $10 \mathrm{~min}$, and dissolved in distilled water. Undissolved materials were removed by centrifugation at $10,000 \times g$ for $10 \mathrm{~min}$. Each $50-\mathrm{ml}$ portion of the solution was passed through a Sephadex G- 25 column $(2 \times 140 \mathrm{~cm})$ to remove ammonium sulfate. Active fractions free from salts were collected and lyophilized.

Step 3. Batchwise treatment with DEAESephadex. The lyophilized powder $(60.4 \mathrm{~g})$ was dissolved in $0.01 \mathrm{M}$ acetate buffer, $\mathrm{pH} 4.0$, and undissolved materials were removed by centrifugation at $8000 \times g$ for $10 \mathrm{~min}$. The solution was treated with DEAE-Sephadex previously equilibrated with $0.01 \mathrm{M}$ acetate buffer, $\mathrm{pH} 4.0$ in a batchwise. Most of cellulase, hemicellulase and colored materials were removed by this treatment.

Step 4. CM-Cellulose column chromatography. The treated solution was applied on a CMcellulose column $(3 \times 55 \mathrm{~cm})$ previously equilibrated with $0.01 \mathrm{M}$ acetate buffer, $\mathrm{pH}$ 4.0. About 40.0 of the activity were passed through the column. After washing with $0.01 \mathrm{M}$ acetate buffer, $\mathrm{pH} 4.0$, the column was eluted successively with $0.05 \mathrm{M}$ acetate buffer, $\mathrm{pH} 4.5$ and $0.1 \mathrm{M}$ acetate buffer, $\mathrm{pH}$ 5.0. Adsorbed activity was eluted from CM-cellulose column

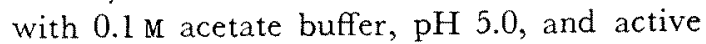
fractions $(200 \mathrm{ml})$ were collected and lyophilized.

Step 5. DEAE-Sephadex column chromatography. The powder obtained in the above step was dissolved in distilled water, and dialyzed against $0.01 \mathrm{M}$ phosphate buffer, $\mathrm{pH} 6.5$ for $24 \mathrm{hr}$. The dialysate was applied on a DEAE-Sephadex column $(2 \times 35 \mathrm{~cm})$ previously equilibrated with $0.01 \mathrm{M}$ phosphate buffer, $\mathrm{pH} 6.5$. After washing with the same buffer, the column was eluted with $0.05 \mathrm{M}$ phosphate buffer, $\mathrm{pH} 6.5$, and active fractions $(120 \mathrm{ml})$ were collected and lyophilized.

Step 6. SE-Sephadex column chromatography (first). The powder obtained in step 5 was dissolved in $0.1 \mathrm{M}$ acetate buffer, $\mathrm{pH} 4.0$ and the solution was dialyzed against the same buffer for $20 \mathrm{hr}$. The dialysate was applied on a SE-Sephadex column $(1 \times 26 \mathrm{~cm})$ previously equilibrated with $0.1 \mathrm{M}$ acetate buffer, $\mathrm{pH}$ 4.0 , and the column was eluted with a linear gradient of concentration of $\mathrm{NaCl}$ in the same buffer. Active fractions $(80 \mathrm{ml})$ were collected and dialyzed against $0.1 \mathrm{M}$ acetate buffer, $\mathrm{pH}$ 4.0 .

Step 7. SE-Sephadex column chromatography (second). The dialysate was again applied on 
a SE-Sephadex column $(1 \times 20 \mathrm{~cm})$ previously equilibrated with $0.1 \mathrm{M}$ acetate buffer, $\mathrm{pH} 4.0$. Elution was performed under the above mentioned condition (Fig. 1). Fractions No. 37 to $40(40 \mathrm{ml})$ were collected, dialyzed against distilled water and lyophilized.

Step 8. Gel filtration with Sephadex G-100. The powder was dissolved in $2 \mathrm{ml}$ of $0.1 \mathrm{M}$ acetate buffer, $\mathrm{pH}$ 5.5, and the solution was applied on a Sephadex G-100 column $(2 \times 140$ $\mathrm{cm})$ previously equilibrated with the same

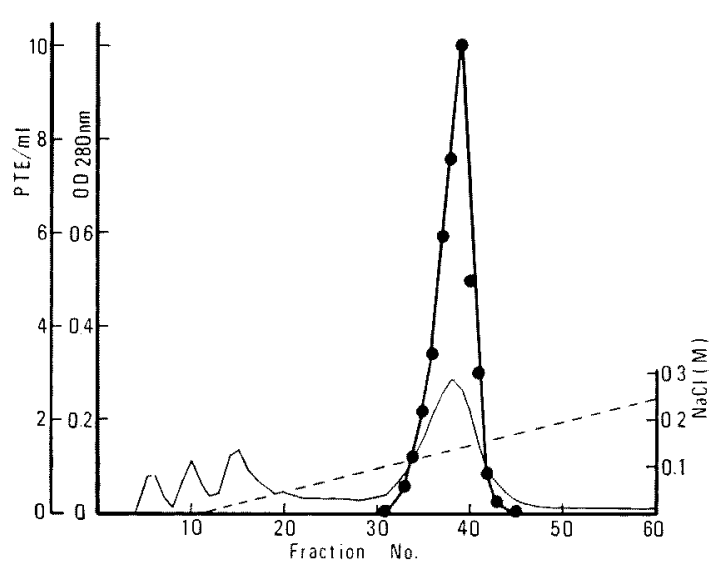

FIG. 1. SE-Sephadex Column Chromatogram.

SE-Sephadex column, $1 \times 20 \mathrm{~cm}$; buffer, $0.1 \mathrm{M}$ acetate buffer, $\mathrm{pH} 4.0$. $\mathrm{NaCl}$ gradient is shown in the figure. Ten $\mathrm{ml}$ fractions were collected.

O.D.280nm - PTE $-\ldots \mathrm{NaCl}$ buffer. The column was eluted with the same buffer. The result is shown in Fig. 2.

Final preparation showed 940 -fold purification over the crude extract. It was almost homogeneous on disc electrophoresis (Fig. 3), and was free from polygalacturonase, hemicellulase and protease. The purification of the enzyme is summarized in Table I.

\section{Properties of the enzyme}

Molecular weight. The molecular weight of

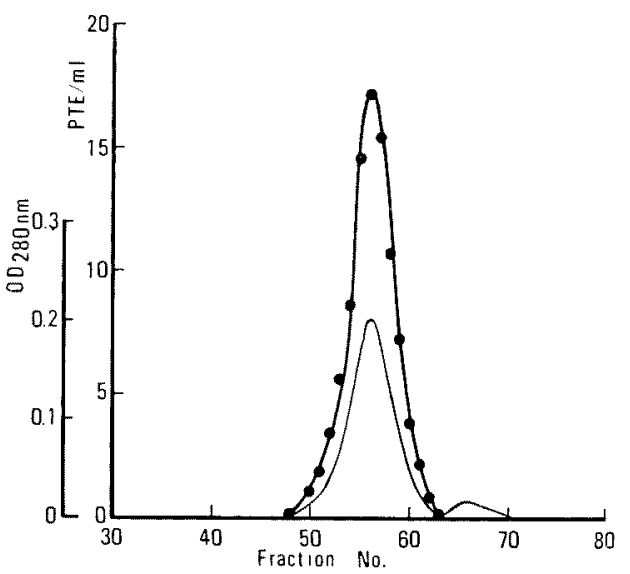

FIG. 2. Gel Filtration of PTE on Sephadex G-100.

Sephadex G-100 column, $2 \times 140 \mathrm{~cm}$; buffer, 0.1 $\mathrm{M}$ acetate buffer, $\mathrm{pH}$ 5.5. Five $\mathrm{ml}$ fractions were collected.

O.D.280nm -P PTE

Table I. Purification of PTE from Aspergillus sojae No. 48

\begin{tabular}{|c|c|c|c|c|c|c|}
\hline & \multirow[b]{2}{*}{ Purification step } & \multirow{2}{*}{$\begin{array}{l}\text { Volume } \\
\text { (ml) }\end{array}$} & \multicolumn{2}{|c|}{ Total } & \multirow{2}{*}{$\begin{array}{l}\text { Specific } \\
\text { activity }\end{array}$} & \multirow{2}{*}{$\begin{array}{c}\text { Yield } \\
(0)\end{array}$} \\
\hline & & & $\begin{array}{c}\text { PTE } \\
\text { (units) }\end{array}$ & $\begin{array}{l}\text { Protein } \\
(\mathrm{mg})\end{array}$ & & \\
\hline 1. & Extraction & 34,000 & 26,690 & 327,760 & 0.081 & 100 \\
\hline 2. & Ammonium sulfate fractionation & 1,353 & 19,930 & 74,415 & 0.268 & 74.7 \\
\hline 3. & Batchwise treatment with DEAE-Sephadex & 480 & 12,720 & 17,808 & 0.714 & 47.6 \\
\hline 4. & CM-Cellulose column chromatography & 200 & 7,216 & 1,278 & 5.65 & 27.0 \\
\hline 5. & DEAE-Sephadex column chromatography & 120 & 3,900 & 148.8 & 26.2 & 14.6 \\
\hline 6. & SE-Sephadex column chromatography (first) & 80 & 1,900 & 34.0 & 55.9 & 7.1 \\
\hline 7. & SE-Sephadex column chromatography (second) & 40 & 1029.6 & 14.2 & 72.5 & 3.9 \\
\hline 8. & Gel filtration with Sephadex G-100 & 35 & 397.8 & 5.2 & 76.5 & 1.5 \\
\hline
\end{tabular}




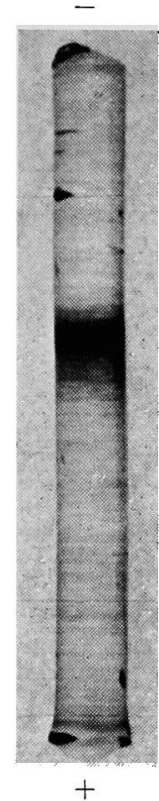

FIG. 3. Disc Electrophoretic Pattern of Purified PTE.

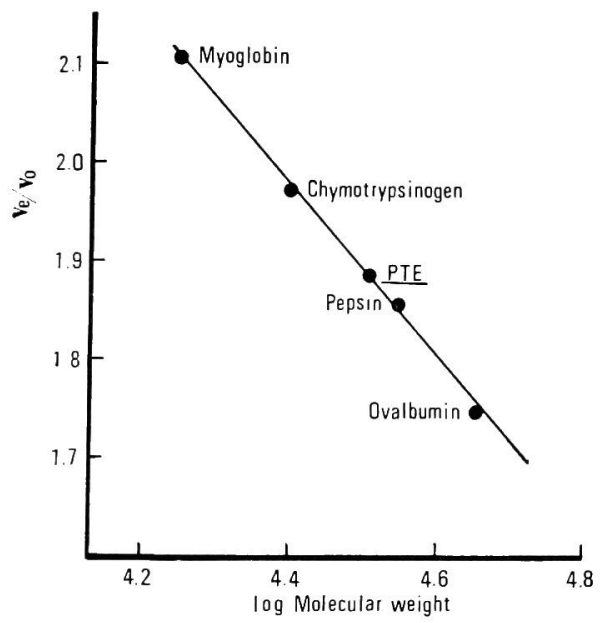

FIG. 4. Estimation of Molecular Weight by Gel Filtration.

PTE and marker proteins $(2 \mathrm{ml})$ were applied on a Sephadex column $(2.5 \times 115 \mathrm{~cm})$ and eluted with $0.1 \mathrm{M}$ acetate buffer, $\mathrm{pH} 5.0$.

PTE was estimated as approximately 32,000 by the Andrews' gel filtration method ${ }^{14)}$ using myoglobin, chymotrypsinogen, pepsin and

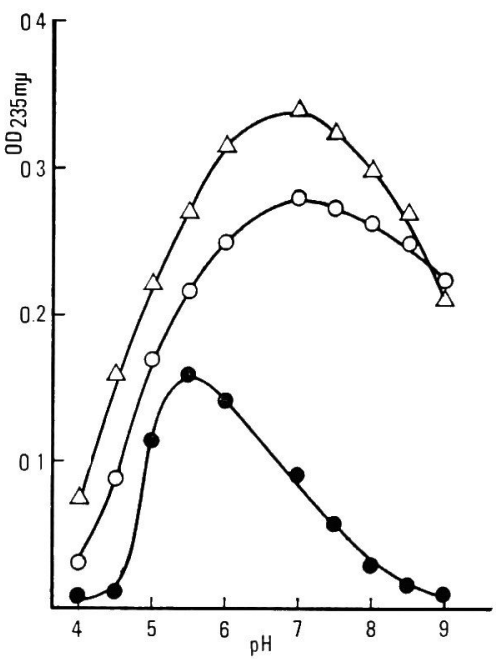

FIG. 5. Effect of $\mathrm{pH}$ on PTE Activity.

Activity was measured in a reaction mixture containing $0.5 \mathrm{ml}$ of enzyme, $1.0 \mathrm{ml}$ of $0.1 \mathrm{M}$ buffer and $1.0 \mathrm{ml}$ of $1 \%$ pectin (or Link pectin) with or without calcium ion.

Acetate buffer was used for $\mathrm{pH} 4$ to 6; Trisacetate buffer for $\mathrm{pH} 7$ to 9 .

- Pectin

O-O Pectin, with $5 \times 10^{-2} \mathrm{M}$ Ca ion

$\triangle-\triangle$ Link pectin.

ovalbumin as reference proteins (Fig. 4).

Effect of $p H$ on the enzyme activity. The effect of $\mathrm{pH}$ on the activity of PTE is shown in Fig. 5. The $\mathrm{pH}$ optimum for the activity lies at 5.5 with pectin as substrate. But the addition of calcium ion (final concn. $5 \times 10^{-2}$ M) to the reaction mixture, shifted $\mathrm{pH}$ optimum to 7.0 accompanied with the stimulation of the activity. If highly esterified pectin (Link pectin) was used as substrate, $\mathrm{pH}$ optimum was found to be around 7.0. When Link pectin was used as substrate, the addition of calcium ion did not cause the stimulation of activity and the change of $\mathrm{pH}$ optimum.

The effect of calcium ion was also observed in the reducing rate of viscosity of pectin. As shown in Fig. 6, the addition of calcium ion stimulated the reducing rate of viscosity 


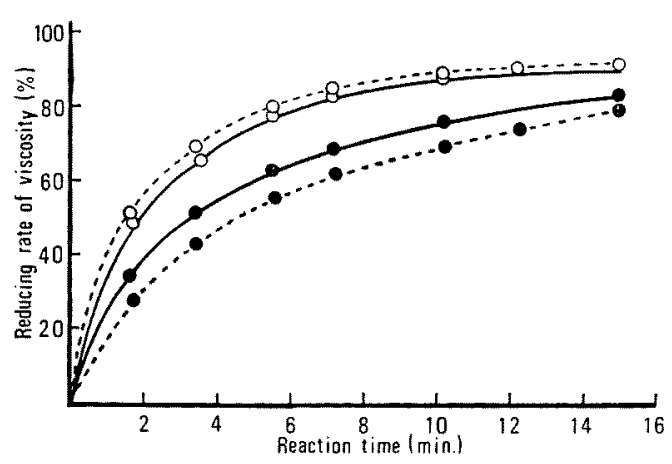

FIG. 6. Reduction of Viscosity of Pectin with or without $\mathrm{Ca}$ ion.

Reaction mixture containing $1.0 \mathrm{ml}$ of enzyme, $3.0 \mathrm{ml}$ of $1 \%$ pectin and $3.0 \mathrm{ml}$ of $0.1 \mathrm{~m}$ acetate buffer, $\mathrm{pH} 5.5$ (tris-acetate buffer for $\mathrm{pH} 7.0$ ) with or without calcium jon, was incubated at $40^{\circ} \mathrm{C}$ in an Ostwald viscosimeter.

- without $\mathrm{Ca}$ ion, $\mathrm{pH} 5.5$

- without $\mathrm{Ca}$ ion, $\mathrm{pH} 7.0$

$0-\mathrm{O}$ with $5 \times 10^{-2} \mathrm{M} \mathrm{Ca}$ ion, $\mathrm{pH} 5.5$

$\mathrm{O}^{-\cdots}$ with $5 \times 10^{-2} \mathrm{M} \mathrm{Ca}$ ion, $\mathrm{pH} 7.0$

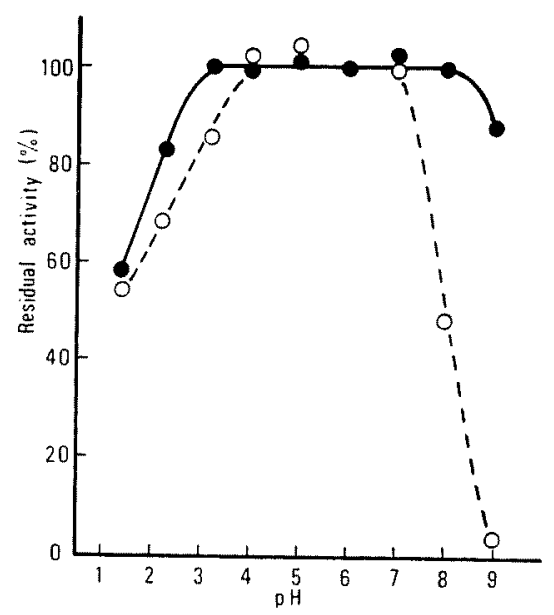

FIG. 7. Effect of $\mathrm{pH}$ on PTE Stability.

$0.05 \mathrm{M}$ sodium acetate- $\mathrm{HCl}$ buffer was used for $\mathrm{pH} 1.5$ to 3.2 ; sodium acetate-acetate buffer for pH 4 to 6 ; tris-acetate buffer for $\mathrm{pH} 7$ to 9 .

- at $4^{\circ} \mathrm{C}$ for $24 \mathrm{hr}$

$0-0$ at $30^{\circ} \mathrm{C}$ for $24 \mathrm{hr}$

at both pHs 5.5 and 7.0. And it was apparent that the reducing rate at $\mathrm{pH} 7.0$ became higher than that at $\mathrm{pH} 5.5$ by the addition

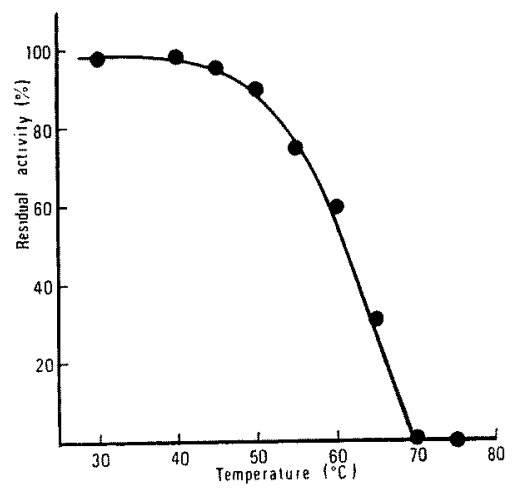

FIG. 8. Effect of Temperature on PTE Stability.

Enzyme was heated in $0.02 \mathrm{M}$ acetate buffer, $\mathrm{pH}$ 5.5 , at various temperatures for $10 \mathrm{~min}$.

of calcium ion.

Stability. Effect of $\mathrm{pH}$ and temperature on the stability of PTE are shown in Figs. 7 and 8 , respectively. The enzyme was quite stable between $\mathrm{pH} 4$ and 7 when incubated at $4^{\circ} \mathrm{C}$ and $30^{\circ} \mathrm{C}$. The enzyme was fairly acid-stable; after storage at $\mathrm{pH} 1.5$ and $30^{\circ} \mathrm{C}$ for $24 \mathrm{hr}, 54,8$ of activity remained.

The enzyme was stable below $40^{\circ} \mathrm{C}$ at $\mathrm{pH}$ 5.5 , but a rapid loss of activity was observed at higher temperatures. Treatment at $70^{\circ} \mathrm{C}$ for $10 \mathrm{~min}$ brought complete loss of activity.

Effect of metal ions on the enzyme activity. The effects of metal ions on the activity were tested using pectin and Link pectin as substrate in $0.05 \mathrm{M}$ acetate buffer, $\mathrm{pH} 5.5$. The addition of divalent cations such as $\mathrm{Ni}^{2+} \cdot \mathrm{Cu}^{2+}$ and $\mathrm{Pb}^{2+}$ to the reaction mixture containing pectin formed too much gel to measure enzyme activity. As shown in Table II, using pectin as substrate, most of divalent cations stimulated the activity by $15 \sim 25 \%$. But when Link pectin was used, these metal ions had no effect on the activation of the enzyme. Both $\mathrm{Cu}^{2+}$ and $\mathrm{Ag}^{+}$had slight inhibitory effect on the activity and $\mathrm{Hg}^{2+}$ showed a remarkable inhibition.

As shown in Table III, optimum concen- 
Table II. EFfect of Metal Ion on PTE ACTIVITY

Reaction mixtures contained $0.5 \mathrm{ml}$ of enzyme, 2 $\mathrm{ml}$ of $0.5 \%$ pectin (or Link pectin) in $0.05 \mathrm{M}$ acetate buffer, $\mathrm{pH} 5.5$, and metal ion (final concentration, $10^{-3} \mathrm{M}$ ).

\begin{tabular}{lrr}
\hline & \multicolumn{2}{c}{ Activity $(0)$} \\
\cline { 2 - 3 } Metal ion & \multicolumn{2}{c}{ Substrate } \\
\cline { 2 - 3 } & Pectin & Link pectin \\
\hline No addition & 100 & 100 \\
$\mathrm{~K}^{+}$ & 108 & 103 \\
$\mathrm{Na}^{+}$ & 104 & 103 \\
$\mathrm{Mg}^{2+}$ & 116 & 98 \\
$\mathrm{Ca}^{2+}$ & 117 & 103 \\
$\mathrm{Mn}^{2+}$ & 121 & 103 \\
$\mathrm{Co}^{2+}$ & 123 & 103 \\
$\mathrm{Ni}^{2+}$ & $-a$ & 99 \\
$\mathrm{Cu}^{2+}$ & $-a\}$ & 81 \\
$\mathrm{Zn}^{2+}$ & 119 & 94 \\
$\mathrm{Ag}^{+}$ & 72 & 90 \\
$\mathrm{Cd}^{2+}$ & 113 & 111 \\
$\mathrm{Ba}^{2+}$ & 124 & 104 \\
$\mathrm{Hg}^{2+}$ & 19 & 25 \\
$\mathrm{~Pb}^{2+}$ & $-a\}$ & 98
\end{tabular}

a) formed gel by the addition of metal ion

Table III. Optimum Concentration of METAL ION

Reaction mixtures contained $0.5 \mathrm{ml}$ of enzyme, 2 $\mathrm{ml}$ of $0.5 \%$ pectin in $0.05 \mathrm{M}$ acetate buffer, $\mathrm{pH} 5.5$, and metal ion.

\begin{tabular}{lccc}
\hline \multirow{2}{*}{$\begin{array}{c}\text { Final conc. } \\
\text { (M) }\end{array}$} & \multicolumn{3}{c}{ Activity $(8)$} \\
\cline { 2 - 4 } & $\mathrm{Na}^{+}$ & $\mathrm{Mg}^{2+}$ & $\mathrm{Ca}^{2+}$ \\
\hline 0 & 100 & 100 & 100 \\
$10^{-4} \mathrm{M}$ & 104 & 106 & 105 \\
$10^{-3} \mathrm{M}$ & 104 & 115 & 118 \\
$10^{-2} \mathrm{M}$ & 113 & 141 & 149 \\
$\mathbf{5} \times 10^{-2} \mathrm{M}$ & 129 & 164 & 167 \\
$10^{-1} \mathrm{M}$ & 139 & 160 & 160 \\
$2 \times 10^{-1} \mathrm{M}$ & 148 & 145 & 134 \\
$3 \times 10^{-1} \mathrm{M}$ & 148 & 128 & 115 \\
\hline
\end{tabular}

tration of metal ion for the activity using pectin as substrate was $5 \times 10^{-2} \mathrm{M}$ for divalent cation and $2 \sim 3 \times 10^{-1} \mathrm{M}$ for monovalent cation.

\section{Table IV. EFfect of Various Substances ON PTE ACTIVITY}

Enzyme and test substances were pre-incubated in $0.05 \mathrm{M}$ acetate buffer, $\mathrm{pH} 5.5$, for $10 \mathrm{~min}$ at $30^{\circ} \mathrm{C}$.

\begin{tabular}{lrr}
\hline \multicolumn{1}{c}{ Substance } & Concn. & $\begin{array}{r}\text { Relative } \\
\text { activity } \\
(\%)\end{array}$ \\
\hline No addition & $10^{-3} \mathrm{M}$ & 100 \\
EDTA & $10^{-3} \mathrm{M}$ & 96 \\
o-Phenanthroline & $10^{-3} \mathrm{M}$ & 99 \\
8-Hydroxyquinoline & $10^{-3} \mathrm{M}$ & 86 \\
p-Chloromercuribenzoate & $2 \times 10^{-4} \mathrm{M}$ & 90 \\
Monoiodoacetic acid & $10^{-3} \mathrm{M}$ & 98 \\
Sodium thioglycolate & $10^{-3} \mathrm{M}$ & 92 \\
Cysteine & $10^{-3} \mathrm{M}$ & 98 \\
Potassium cyanide & $10^{-3} \mathrm{M}$ & 100 \\
N-Bromosuccinimide & $10^{-3} \mathrm{M}$ & 2 \\
lodine & $10^{-3} \mathrm{M}$ & 11 \\
\hline
\end{tabular}

Table V. Eliminative Cleavage of Polyuronic Compounds by Purified ENzyME

Reaction mixtures containing $0.5 \mathrm{ml}$ of enzyme, $1.0 \mathrm{ml}$ of $1 \%$ substrate and $1.0 \mathrm{ml}$ of Mcllvaine buffer, were incubated at $40^{\circ} \mathrm{C}$ for $60 \mathrm{~min}$.

\begin{tabular}{lcc}
\hline \multicolumn{1}{c}{ Substrate } & pH & $\begin{array}{c}\text { Increase in absorb- } \\
\text { ance at } 235 \mathrm{~m} \mu\end{array}$ \\
\hline Pectin & 5.5 & 31.2 \\
Link pectin & 5.5 & 60.8 \\
Pectic acid & 4.5 & 0 \\
Alginic acid & 5.5 & 0 \\
Chondroitinsulfate & 5.0 & 0 \\
\hline
\end{tabular}

Effect of various substances on the enzyme activity. As shown in Table IV, metal chelating reagents did not show inhibitory effect on the activity. The enzyme activity was not affected by reducing reagents and those reagents which convert $\mathrm{SH}$ groups in protein into mercaptides. In contrast, such oxidizing reagents as N-bromosuccinimide and iodine caused severe inactivation.

Specificity. The purified enzyme was specific for $\alpha-1,4$ methylesterified galacturonide linkage. It could not attack $\alpha-1,4$ nonesterified galacturonide linkage (pectic acid), $\beta-1,4$ 

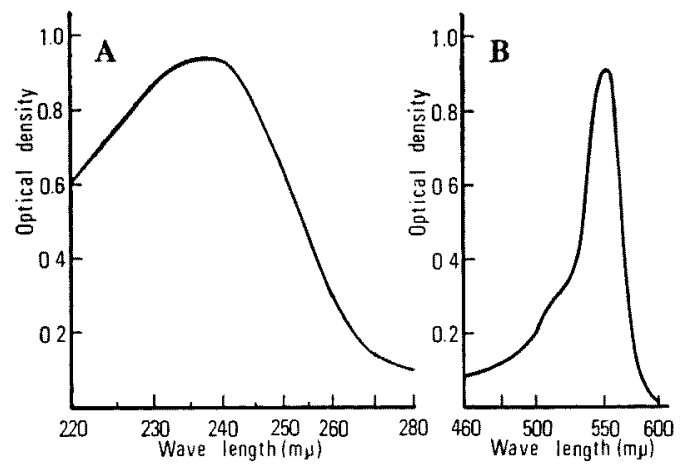

FIG. 9. A) Absorption Spectrum of Reaction Products. B) Absorption Spectrum of Thiobarbituric Acid Reaction Products.

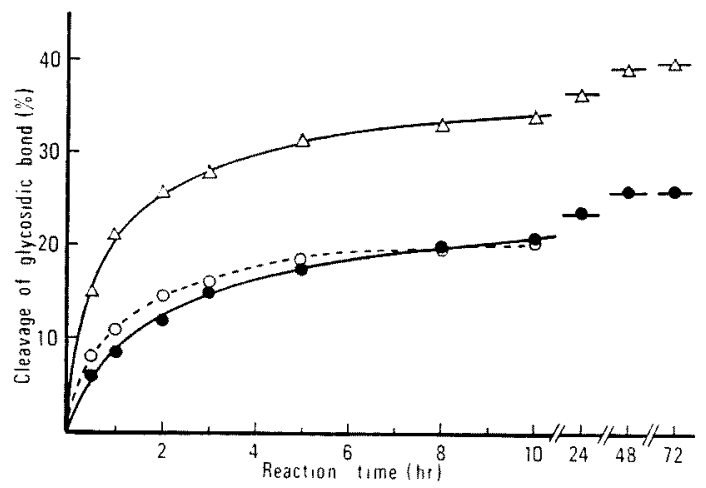

FIG. 10. Cleavage of Glycosidic Bond by PTE

Reaction mixture contained $200 \mathrm{mg}$ of substrate in $20 \mathrm{ml}$ of $0.05 \mathrm{M}$ acetate buffer, pH $5.5(0.05 \mathrm{M}$ tris-acetate buffer, $\mathrm{pH} 7.0$ for Link pectin) and 17 units of enzyme. Temperature: $40^{\circ} \mathrm{C}$.

- Pectin

$0-\mathrm{O}$ Pectin, with $5 \times 10^{-2} \mathrm{M} \mathrm{Ca}$ ion

$\triangle-\Delta$ Link pectin

mannuronide and guluronide linkage (alginic acid), and chondroitin sulfate (Table V).

Absorption spectrum of reaction products. The absorption spectrum of reaction products of Link pectin in the ultraviolet region is shown in Fig. $9 \mathrm{~A}$. The reaction products, supposedly 4,5-unsaturated methyl galacturonides, had an absorption maximum at $238 \mathrm{~m} \mu$. This value was rather higher than that reported by Albersheim et al. ${ }^{1}$

When 4, 5-unsaturated methyl galacturonides were allowed to react with thiobarbituric acid, ${ }^{16}$ the reaction products had an absorption maximum around $552 \mathrm{~m} \mu$ (Fig. $9 \mathrm{~B}$ ). This value was also higher than that reported by Albersheim et al. ${ }^{11}$

Cleavage of glycosidic linkage by PTE. The rates of cleavage of glycosidic linkages in pectin and Link pectin were followed by measuring the liberated aldehyde groups determined by iodometric method. ${ }^{16}$ When pectin was used as substrate, the experiments were done both in the presence and absence of $5 \times 10^{-2} \mathrm{M} \mathrm{CaCl}_{2}$ in the reaction mixture. The results are shown in Fig. 10. Calcium ion increased the initial rate of reaction, but had no effect on the degradation extent of pectin, which was $26.3 \%$ after $48 \mathrm{hr}$. On the other hand, the degradation of Link pectin extended up to $39.7 \%$ after $72 \mathrm{hr}$.

\section{DISCUSSION}

PTE from Asp. sojae was purified by means of ammonium sulfate fractionation, batchwise treatment with DEAE-Sephadex, ion exchange column chromatography and gel filtration. The purified enzyme was almost homogeneous on disc electrophoresis and was free from polygalacturonase, hemicellulase, cellulase and protease. But the yield of final preparation was very low.

Molecular weight of PTE, which had not been reported previously, was about 32,000 in Asp. sojae. This value is quite similar to those of endo-pectic acid transeliminase from Erwinia carotovora $(31,000)^{171}$ and Erwinia chrysanthemi $(30,000 \sim 32,400){ }^{181}$

Optimum $\mathrm{pH}$ of PTE was 5.5 with pectin as substrate. This $\mathrm{pH}$ value is close to that reported previously., ${ }^{1,7)}$ But when Link pectin was used as substrate, $\mathrm{pH}$ optimum of the enzyme exhibited 7.0. And if $5 \times 10^{-2} \mathrm{M} \mathrm{CaCl}_{2}$ was added to the reaction mixture, the $\mathrm{pH}$ 
optimum for pectin shifted to neutral side. The same effect of calcium ion for pectin was observed in the reducing rate of viscosity.

Only when pectin was used as substrate, activity of PTE was stimulated by divalent cations. As shown in Table III, optimum concentration of divalent cation was found to be high. Although calcium ion increased the initial rate of reaction, it did not extend the limit of degradation of pectin.

These results suggested that cations, especially divalent cations might have a strong affinity for about $30 \%$ of free carboxyl groups in pectin, and reduce the negative charge of the substrate especially at $\mathrm{pH}$ above 5.5 . Consequently, pectin will have more affinity for the enzyme. This resulted in the stimulation of activity and the shift of $\mathrm{pH}$ optimum by the addition of divalent cations.

PTE of Asp. sojae degraded glycosidic linkages in pectin and Link pectin up to 26.3 and $39.7 \%$, respectively. These degradation extents were higher than those obtained by Asp. fonsecaeus. ${ }^{7}$ ' The result suggests that the specificity of Asp. sojae PTE for methyl esterified oligogalacturonides may be rather lower than that of Asp. fonsecaeus PTE. Since PTE from Asp. fonsecaeus could not attack the trimer and low methyl esterified galacturonides, exhaustive degradation of Link pectin by the enzyme yielded mainly unsaturated tri-, tetra- and penta-methyl esterified galacturonides. ${ }^{7}$ But in the case of Asp. sojae, low methyl esterified galacturonides than trimer seem to have been formed from Link pectin as detected by paper chromatography and gel filtration. Further studies will be done to identify these reaction products.
Acknowledgment. The authors wish to thank Miss Hatsue Aishima for her technical assistance.

\section{REFERENCES}

1) P. Albersheim, H. Neukom and H. Deuel, Helv. Chim. Acta, 43, 1422 (1960).

2) K. Okamoto, C. Hatanaka and J. Ozawa, Agr. Biol. Chem., 28, 331 (1964).

3) J. D. Macmillan and R. H. Vaughn, Biochem, 3, 564, 572 (1964).

4) S. Nasuno and M. P. Starr, Biochem. $J$, 104, 178 (1967).

5) L. Miller and J. D. Macmillan, J. Bacteriol, 102, $72(1970)$.

6) P. Albersheim and U. Killias, Arch. Biochem. Biophys., 97, 107 (196?).

7) R. D. Edstrom and H. J. Phaff, J. Biol. Chem., 239, 2403, 2409 (1964).

8) D. A. Bush and R. C. Codner, Phytochem., 9, 87 (1970).

9) S. Ishii, S. Kawamura and T. Yokotsuka, Nippon Nogeikagaku Kaishi, 44, 299 (1970).

10) S. Ishii and T. Yokotsuka, Agr. Biol. Chem., 35, 1157 (1971).

11) S. Ishii and T. Yokotsuka, J. Agr. Food Chem., 19, 958 (1971).

12) S. Morell and K. P. Link, J. Biol. Chem, 100, 385 (1933); S. Morell, L. Baur and K. P. Link, ibid., 105, 1 (1934).

13) C. H. Lowry, N. J. Rosebrough, A. L. Farr and R. J. Randall, ibid., 193, 265 (1951).

14) P. Andrews, Biochem. J., 91, 222 (1964).

15) A. Weissbach and J. Hurwitz, J. Biol. Chem., 234, 705 (1959).

16) C. Hatanaka, Nippon Nogeikagaku Kaishi, 41, 448 (1967).

17) M.S. Mount, D. F. Bateman and H. G. Basham, Phytopathol., 60, 924 (1970).

18) A. Garibaldi and D. F. Bateman, Phytophathol. Mediter., 9, 136 (1970). 